\title{
RESEÑAS BIBLIGRÁFICAS
}

Leoni, Ma. Silvia; Solís Carnicer, Ma. Del Mar. (Compiladoras) La politica en los espacios subnacionales. Provincias y Territorios en el nordeste argentino (1880-1955). Rosario, Prohistoria, 2012. Pp. 274.

María S. Leoni y María del Mar Solís Carnicer nos presentan, en calidad de compiladoras y también de autoras, La política en los espacios subnacionales. Provincias y Territorios en el nordeste argentino (1880-1955), una obra que se convertirá en referencia para quienes se interesen en la temática o se inicien en la investigación de problemáticas referidas a la historia política regional, por sus aportes y enfoques acerca de un tema, período y espacio sobre el que no abunda bibliografía específica.

Desde la creación de la Universidad Nacional del Nordeste, y canalizando su acción principalmente a través del Instituto de Historia de la Facultad de Humanidades y del Instituto de Investigaciones Geohistóricas -CONICET/UNNE-, los historiadores del Nordeste argentino han abordado el estudio de la historia política, inicialmente a través una perspectiva institucional; desde las tareas de los gobiernos provinciales, los acontecimientos políticos militares o las biografías de los actores. Ha sido el caso de Corrientes, preocupada por su historia políticoinstitucional y el papel de la provincia en el proceso de organización nacional. Por su parte, las provincias que fueran territorios nacionales han buscado también reconstruir su historia política, y por ello han recuperado las gestiones de gobernadores, la trayectoria institucional. Desde el trabajo de historiadores de la región y desde el interés y aportes de investigadores de otras regiones del país, se han empezado a construir, consolidar y comparar enfoques centrados en los movimientos y partidos políticos, la vida comunal y los procesos de provincialización de estos espacios específicos. Superando serios obstáculos, dispersión, fragmentación, difícil y desigual acceso a recursos, bibliografía, documentos; los investigadores del nordeste argentino han logrado introducir nuevas perspectivas en la historiografía política de la región.

En este panorama, "La política en los espacios subnacionales. Provincias y Territorios en el nordeste argentino (1880-1955)" constituye un valioso aporte y un precedente, ya que viene a poner en evidencia, por un lado el desarrollo de la historiografía regional y por otro, hace sobresalir el trabajo de estos historiadores que han consolidado un campo regional de investigación, de intercambio con otros investigadores y análisis acerca de la historia política regional, cubriendo un espacio y un tiempo que, como mencionamos, ha sido insuficientemente transitado hasta hace muy poco, y que no es de ningún modo un espacio vacío.

Con la colaboración de investigadores reconocidos, a los que se suma el aporte de jóvenes historiadores, la obra, nos invita a reflexionar acerca del papel y aportes de las regiones y provincias la conformación de una historia política nacional en la que se evidencie la articulación existente entre lo local, regional y nacional. 
Centrada la obra en "indagar sobre el lugar que ocupó la región en la construcción de la vida política nacional, analizar la dinámica, organización y composición de los partidos políticos en los contextos subnacionales de Corrientes, Chaco y Formosa, precisar los mecanismos de control político y de administración, la composición y transformaciones de los núcleos de poder locales, los actores sociales y políticos más relevantes, y determinar así las continuidades y rupturas que se perciben en la estructura y en las lealtades políticas... buscamos establecer las interacciones entre las instituciones, los valores y los actores." (Leoni, M.S.; Solís Carnicer, M.M.: 2012: 16), los artículos compilados abordan diversas cuestiones referidas a la historia política de Corrientes y Chaco y, en menor medida, de Santa Fe y Formosa. Las autoras y compiladoras, María Silvia Leoni de Rosciani y María del Mar Solís Carnicer, en una sintética y lúcida Introducción nos acercan a los detalles más relevantes de la temática, la trayectoria de los estudios políticos en la región, la justificación de la realización de esta obra, importante para los anales de nuestra producción historiográfica regional, así como también nos introduce en la definición de algunas categorías necesarias para la comprensión cabal de los textos y los objetivos que se persiguen. Se han incluido además, como parte del libro, tres escritos que, si bien no se circunscriben al espacio-objeto de estudio ni provienen de investigadores relacionados con su examen, plantean cuestiones centrales relativas a la historia política regional. En el primero de estos escritos, Pasado y Presente. Las historias provinciales y territoriales a debate en el marco de la restitución de la historia política, Marta Bonaudo propone redefinir el concepto de hecho político desde la óptica de su incidencia en la construcción del Estado y de las nuevas comunidades políticas. A continuación, Darío Macor, en el artículo La década de 1930 en la historiografía argentina, analiza la producción historiográfica que reconstruyó y caracterizó esa década, destacando la contribución de los estudios subnacionales en ese contexto. Finalmente César Tcach propone, desde Córdoba y sus metáforas. En torno a su rol en la historia política nacional, reflexionar acerca de los usos y funcionamiento de conceptos de región, historia provincial, historia regional en vinculación con la construcción de la historia política de espacios subnacionales; partiendo del análisis de diversas metáforas discursivas generadas por la presencia de Córdoba en la política nacional.

En el campo de la temática específica de la obra; el artículo Las finanzas públicas de la provincia de Corrientes durante la segunda mitad del siglo XIX, de Enrique Shaller nos introduce en el examen de la evolución de las finanzas públicas provinciales desde la sanción de la Constitución Nacional, analizando el fuerte impacto que tuvieron en el sistema fiscal provincial, las luchas políticas e interpartidarias. En La legislación electoral correntina a fines del siglo XIX. Características, modismos y prácticas locales, Dardo Ramírez Braschi analiza dicha legislación en el contexto de consolidación del sistema eleccionario provincial, que no estuvo exento, por otra parte de ser un espacio de rivalidad política de dos fuerzas en disputa en el período en estudio.

Natacha Bacolla, en Debates, prácticas politicas y reforma institucional en las entreguerras. Un análisis desde el caso santafesino, se sitúa en este espacio durante los últimos años de la década de 1930, para analizar las relaciones entre estado y sociedad, mediante las tensiones que se ponen en evidencia en el cambio institucional propiciado por el Estado provincial y en el que las elites, por un lado, y los sectores populares, por otro intentarán canalizar recursos para intervenir exitosamente en este proceso.

El artículo de Ana D. Ruzich, Política, partidos y elecciones en los municipios de Resistencia y Presidencia Roque Saenz Peña (1930-1943), examina la vida política municipal, describe las organizaciones partidarias, el desarrollo y resultado de los actos eleccionarios en 
dos importantes municipios del entonces Territorio Nacional del Chaco. Por su parte, María Silvia Leoni reconstruye la conformación y accionar de los núcleos de poder locales y la identificación de actores sociales y políticos que intervinieron o buscaron intervenir en la designación de gobernadores para el Territorio. Para ello aborda, en Vínculos entre la política nacional, regional y local. La designación de gobernadores en los Territorios Nacionales, la interacción de gobiernos, partidos y grupos de poder territorianos y de las provincias vecinas en ocasión de aproximarse una designación de gobernadores.

En Continuidades y rupturas en la politica de tierras en el Territorio Nacional del Chaco (1930-1943), Adrián Almirón releva las políticas de tierras y las medidas adoptadas desde el gobierno nacional respecto a la tierra pública, los debates en el Congreso nacional respecto al tema y analiza el impacto de esas políticas en el Chaco.

María del Mar Solís Carnicer en su artículo Diseñando una provincia peronista. Nueva Constitución, nuevo sistema electoral y nuevo sistema de partidos. Corrientes (1945-1955), explica las transformaciones institucionales acaecidas tras la llegada del peronismo al poder en la provincia y cómo esas transformaciones incidieron en las prácticas políticas de las elites correntinas y también en el sistema político provincial.

El texto de Hugo Beck, Origen del peronismo formoseño y autonomía provincial. 19461955, recorre el proceso de formación del peronismo formoseño, atravesado por los conflictos ideológicos y discusiones internas en el marco de los inicios del proceso de provincialización.

Mayra Maggio reconstruye los orígenes del peronismo chaqueño, describiendo la configuración del espacio político chaqueño en El peronismo en el Chaco. Una aproximación a sus orígenes, y la tensión e interacción de diferentes fuerzas y agrupaciones que se sumarían, no sin conflictos, a este movimiento. Finalmente, Política agraria del primer peronismo. Objeciones y anhelos de las cooperativas agrícolas del Chaco, de Leandro Moglia, revisa las medidas aplicadas por el peronismo en torno al régimen legal de la tierra y al asalariado rural y cómo estas medidas incidieron en las problemáticas y relaciones con las cooperativas del Territorio, un actor de peso en el ámbito rural del período.

La obra hasta aquí reseñada exhibe la profesionalidad de los autores y de las compiladoras y constituye un texto que consolida la representatividad y aportes del Nordeste a la Historiografía Argentina. De allí que la vigencia y pertinencia del tema, que viene en realidad a cubrir un vacío en la historiografía regional, sea otro de los puntos destacables de $L a$ politica en los espacios subnacionales. Provincias y Territorios en el nordeste argentino (18801955), junto a la construcción y difusión de conocimiento acerca de nuestra propia historia política regional. Difusión que se hace, por otra parte en un lenguaje claro y conciso; destacando conceptos, relaciones, categorías y procesos que caracterizan a esta, nuestra historia política regional.-

María Zurlo 